\title{
Older shopper types from store image factors
}

\author{
Robert J. Angell ${ }^{a}$, Phil Megicks ${ }^{b}$, Juliet Memery ${ }^{c, *}$, Troy W. Heffernan ${ }^{b}$ \\ a Cardiff Business School, Cardiff University, Colum Drive, Cardiff, CF10 3EU, UK \\ b Plymouth Business School, Plymouth University, Drake Circus, Plymouth, Devon, PL4 8AA, UK \\ ${ }^{\mathrm{c}}$ The Business School, Bournemouth University, 89 Holdenhurst Road, Bournemouth, Dorset, BH8 8EB, UK
}

\section{A R T I C L E I N F O}

Article history:

Received 24 July 2013

Accepted 24 July 2013

\section{Keywords:}

Older shoppers

Shopper typology

Grocery shopping

Store choice

Cluster analysis

\begin{abstract}
A B S T R A C T
This study aims to characterise the older shopper by exploring unobserved heterogeneity within the segment and developing an older shopper typology from an empirically derived store image scale. Store attribute theory informed a two-stage research design. Firstly, a 'pool' of salient store attributes was identified through in-depth interviews. Scales were then developed and quantitatively tested using data collected through a household postal survey. Seven store image factors emerged, forming the basis of the typology. Five clusters were subsequently profiled using behavioural and demographic variables: Prudent neutrals, All-Round demanders, Reluctant casuals, Demanding sociables, and Affluent utilitarians. A discussion of the resultant classification's utility in terms of retail strategy, including opportunities for better targeting through adjustment of the retail offer, is presented. This study develops a store image scale that reflects the importance of store choice decisions of older shoppers, extending store image research by providing contemporary insights into the requirements of older shoppers in a changing retail environment.
\end{abstract}

(c) 2013 Elsevier Ltd. All rights reserved.

\section{Introduction}

Older consumers $(60+$ years) are now commanding greater academic and practitioner attention, with businesses and researchers recognizing that this group possesses the key characteristics to justify targeted selection in the marketplace (Chaston, 2011; Yoon et al., 2009). Official national statistics indicate that $23 \%$ of the UK population will be 65 years and above by 2034, an increase of $8 \%$ from 1984 (ONS, 2011). Retailers responsive and adaptable to the needs of older customers are thought able to leverage increased financial benefits from their considerable spending power (Thompson and Thompson, 2009). However, in order to do so effectively, retailers are increasingly being required to consider older consumers as a heterogeneous group (Yoon et al., 2009). Similarly, researchers are being encouraged to identify the similarities and differences in retail engagement (Lumpkin, 1985) within this segment, particularly unobserved heterogeneity (Ahmad, 2002; Teller and Gittenberger, 2011). Despite limited research, many believe the current older generation to be significantly different from its predecessor (Myers and Lumbers, 2008; Thompson and Thompson, 2009) and, consequently, worthy of more attention and study.

Yoon et al. (2009) investigated heterogeneity in older consumers on the basis of understanding how ageing affects consumer

\footnotetext{
* Corresponding author. Tel.: +44 1202968743.

E-mail address: jmemery@bournemouth.ac.uk (J. Memery).
}

decision making. Through developing a person-context fit framework of consumer decision making they concluded that older people with greater consumer experience and expertise are often competent in making decisions. However where competence is affected by greater environmental demands older consumers may apply strategies to mitigate these effects i.e. they adapt themselves (Yoon et al., 2009), determined by emotional responses to situational conditions (Carstensen, 2006; Labouvie-Vief, 2009). Where it is not possible for such adaptations to take place there is a call for marketers to assist decision-making through the use of appropriate marketing mix tools, based on a profound understanding of consumer needs (Yoon et al., 2009) and recognition of the contextual factors which interact with age (Yoon et al., 2005).

Consumer decision making styles can be characterised by the consumer typology approach (Sproles and Sproles, 1990). Classifying shoppers into subgroups by developing typologies has been, for several decades, a common procedure when modelling consumer heterogeneity (Reynolds et al., 2002). This has enriched the wider development of consumer behaviour, consumer decisionmaking and shopping theories, whilst enabling practitioner's greater scope for targeting and positioning strategies (Westbrook and Black, 1985). A number of studies have developed typologies on the basis of decision-making traits (for a literature review, see Mitchell and Bates, 1998). Sprotles and Kendall (1986) devised the Consumer Styles Inventory (CSI) for their studies of student shopper decision making traits in the US. Further studies applied this scale to test multi-cultural applications (Canabal, 2002; 
Fan and Xiao, 1998; Lysonski et al., 1996), however many of these investigations also used student samples and there is little evidence of the CSI being applied to older age segments. The applicability of a scale designed with a view to younger consumers has obvious limitations, particularly as the language used and dominant resultant typologies (Chase et al., 2007) are unlikely to reflect older consumer's experiences and language, and therefore scales for specialist population segments are recommended (Mitchell and Bates, 1998).

An alternative approach to establishing shopper typologies has been built on the solid foundations of store attribute theory in which consumers form an assessment of a retail store by ascribing varied levels of importance to components of its wider formation-otherwise known as store image (Bellenger et al., 1977; Darden and Ashton, 1975; Ganesh et al., 2007; Karande and Ganesh, 2000). Consequently, theories of store image have retained an established position in retailing and shopping theory, where the emphasis has predominantly been on the classification of store image attributes and factors (Kunkel and Berry, 1968; Lindquist, 1974-1975; Martineau, 1958; Zimmer and Golden, 1988). Whilst a handful of seminal studies have both formed the foundations of, and enriched, a plethora of empirical investigations, it is unknown how robust these theories stand when applied (1) in contemporary retail settings, and (2) with specific groups of consumers. The latter issue is progressively important with researchers stressing the need for greater illumination of smaller and more defined segments (e.g. Breazeale and Lueg, 2011; Reynolds et al., 2002).

The current study is positioned in the UK grocery sector. As the previous comments demonstrate, a new distinct store image scale is required in order to measure the attributes that match older consumer's distinctive shopping 'needs' and 'wants' (see Goodwin and Mcelwee, 1999; Lambert, 1979; Meneely et al., 2009; Pettigrew et al., 2005). A combination of 'store image' and 'older consumer' research informs the empirical development of a new scale, which is subsequently used to satisfy the requirement for an age-based typology, namely for older shoppers (Breazeale and Lueg, 2011; Sudbury and Simcock, 2009). This builds upon previous research within this context that has focused on a creating a qualitative typology from the literature and in-depth interviews (Angell et al., 2012). This extends this work using a more rigorous and scientific procedure.

This article begins by reviewing both shopper typology and store image literature before presenting the empirical research process employed in this study. A series of conclusions are drawn from the findings, providing implications for theory, retail practice and future research.

\section{Conceptual background}

\subsection{Shopper types}

A number of studies have successfully constructed shopper typologies in a range of settings (Bellenger and Korgaonkar, 1980; Darden and Reynolds, 1971; Reynolds et al., 2002), utilising a mixture of methods (Moschis, 1976; Westbrook and Black, 1985) and sampling groups (Arnold and Reynolds, 2003; Breazeale and Lueg, 2011). The earliest example of customer profiling originates in the work of Stone (1954) who identified different types of urban shopper. This trend continued in the work of other researchers who used motivational attributes as the basis for segmentation (e.g. Guiot and Roux, 2010; Jarratt, 1996; Reynolds and Beatty, 1999; Tauber, 1972; Westbrook and Black, 1985). In variations of this approach, other studies have used store image attributes as an alternative to motivational items with the intention of locating aspects of the store having higher (or lower) importance to different customers (Hansen and Deutscher, 1977-1978;
Memery et al., 2012; Reynolds et al., 2002). The objective is to classify shoppers into meaningful groups by assessing variations in a series of focal attributes. For instance, Reynolds et al. (2002) identified six traditional and mall shopper types from 17 store attributes; namely Basic, Apathetic, Destination, Enthusiasts, Serious, and Brand. In recent years, research has started to consider the development of profiling for more specific groups of customers e.g. cultures (Jin and Kim, 2003; Theodoridis and Chatzipanagiotou, 2009), genders (Shim and Kotsiopoulos, 1993) and age groups (Breazeale and Lueg, 2011). Sudbury and Simcock (2009) categorised 50-79 year old shoppers in the UK using a wide range of ageing and behavioural variables derived from gerontology literature and consumer research. They found five clusters in the older consumer market-solitary sceptics, bargain hunting belongers, self-assured sociables, positive pioneers and cautious comfortables. However, three of these clusters had an average chronological age of under 60 years and few of the scales used were associated with store image attributes, thus inhibiting meaningful marketing management decision making for specific aspects of the retail offer.

\subsection{Store image}

Store image has appeared in the extant literature since the seminal work of Martineau (1958) who described it as fusing functional qualities and psychological attributes comprising the retail store. Despite its rich heritage, there remains little clarity in how store image should be conceptualized (Hartman and Spiro, 2005). Most definitions confirm that store image is a holistic measurement in which the shopper assesses components forming constituent parts of their store evaluations (Doyle and Fenwick, 1974). It is therefore a multi-attribute construct (James et al., 1976; Theodoridis and Chatzipanagiotou, 2009) where the overall impression is greater than the sum of the parts (Oxenfeldt, 1974-1975).

Debates have centred on the appropriate construction and measurement of store image (Buttle, 1985; Samli et al., 1998). In the seminal article by Martineau (1958), four key attributes were identified: layout and architecture, symbols and colour, advertising, and sales personnel. Kunkel and Berry (1968) later developed this to include 12 dimensions, each comprising between three and seven attributes. Lindquist (1974-1975) reviewed 26 research papers representing the most commonly cited store image studies. He compiled a list of nine factors: merchandise, service, clientele, physical facilities, convenience, promotion, store atmosphere, institutional factors and post-transaction satisfaction. He suggested that these comprised various attribute-level considerations, but confirmed that previous research, on which his article was based, showed merchandise to be the most salient dimension of image when viewed through a consumer lens. Hansen and Deutscher (1977-1978) extended earlier research to produce a quantitative instrument that yielded a list of 41 variables, constituting the most important variables to shoppers when selecting a grocery and department store. These were subsequently ranked and compared across both types of retailer.

Zimmer and Golden (1988) later attacked the lack of empirical, inductive research in previous developments of store image theory. Following a rigorous qualitative content analysis procedure 47 attributes were derived, representing seven dimensions. They argue that this more deeply captured retail store image than past studies, claiming their taxonomy was unique in terms of its inquiry, particularly in light of the fact that previous research had been dominated mostly by deductive applications.

The evidence presented thus far is compelling in its implications for store image research. However, in common with the body of consumer typology research, previous store image research has tended to ignore older consumers' use of 'specific' attributes to evaluate retail experiences (e.g. Bearden and Mason, 1979; Hare 
et al., 1999; Lambert, 1979). Assuming a generic perception of retail store image is likely to be poorly conceived (Gunter, 1998; Moschis, 1992). As such, an empirically derived scale constructed from store attributes rather than self-attributes as a basis for an empirical typology of older shoppers is considered to represent a useful and necessary development containing both theoretical and practical merit.

\section{Methodology}

The empirical research undertaken in this study relies heavily on the scale development paradigm sanctioned by authorities such as Churchill (1979), DeVellis (2003), Gerbing and Anderson (1988) and Peter (1981). A mixed-method procedure, in line with the sequential transformative approach endorsed by Cresswell (2002) was adopted, with qualitative research informing a later stage of quantitative research. Analysis was conducted using a series of statistical tests; namely exploratory factor analysis, confirmatory factor analysis and cluster analysis.

\subsection{Qualitative research}

Thirty six in-depth interviews were used to elicit store image attributes important to older people when shopping for groceries. Participants were 60 years and older (in line with recent studies; e.g. Meneely et al., 2009) and responsible for doing their household's grocery shopping. People were recruited using six different local and national social organisations for older people resulting in a mix of participants ranging in age, gender, socio-economic and geographical characteristics.

Given the lack of precedency, a fairly unstructured interviewing approach was adopted. Interviews aimed to identify both what issues were considered salient to the respondents and why, as well as the benefits they expected to accrue (Seidman, 2006). A content analysis procedure was followed to identify themes in the data (Zimmer and Golden, 1988). Two analysts independently coded recurring attributes, which were then placed into more general categories. A panel of university professors in the areas of marketing and research methodology assessed the content validity of items for the quantitative research instrument (DeVellis, 2003). The number of store image attributes for quantitative exploration consequently reduced from 50 to 42 items.

\subsection{Qualitative results}

A framework of attributes (see Appendix) underlying eight store image factors was identified: Accessibility, Merchandise, Physical Environment, Atmospheric Environment, Price \& Promotions, Services, Personnel and Clientele factors. In general, the findings provide a natural extension to previous work (e.g. Kunkel and Berry, 1968; Lindquist, 1974-1975; Martineau, 1958; Zimmer and Golden, 1988), consolidating attributes into a single framework and inducting new theory.

The first factor is Accessibility, which measured distance to the store, availability of car parking, store opening times, and perceived accessibility. The interviews revealed attributes similar to Kunkel and Berry (1968), with an extension being the importance of a well-served network of bus routes. This emerged as an important variable as many respondents relied heavily on public transport (e.g. Meneely et al., 2009).

Merchandise is well established in-store image theory (Dickson and Albaum, 1977; Kunkel and Berry, 1968; Lindquist, 1974-1975). It has previously incorporated components ranging from store 'quality', 'selection' and 'price' (Lindquist, 1974-1975), to availability of 'brand names' and 'assortment' (Kunkel and Berry, 1968). Whilst these items were found to be relevant in this context (see Appendix) older shoppers displayed an interest in having a wide range of 'product sizes', 'dietary products', as well as 'clear product information' on packaging. A range of product sizes was found to be especially salient; a finding documented in several studies (e.g. Hare et al., 1999; Mason and Bearden, 1978). One person commented that his generation disliked wasting food, which was a problem if products were not available in the required size: "I was born in the war and we didn't waste food. However it's catch 22 as I cannot be eating such large portions". Some respondents claimed to have problems reading product labels due to font size, resulting in, at times, purchasing unexpected goods. As such, having clearly stated and appropriately sized wording on products is critical (e.g. Lambert, 1979; Meneely et al., 2009). The availability of special dietary products was found to be a direct consequence of the heightened health consciousness amongst older people. Whilst, this represents a new theme in retail theory, the onset of age related illnesses such as diabetes has been discussed in previous work (see Gunter, 1998; Moschis, 1992).

The Physical Environment being distinct from the Atmospheric Environment was clear, supporting Lindquist (1974-1975). He noted the importance of elevators, lighting, temperature, washrooms, aisle placement, store layout and architecture, aspects that were found to be evident amongst older shoppers also. Some clear extensions were identified: reachable shelf heights were noted amongst those with physical acuities (e.g. Meneely et al., 2009); wider aisles were considered as a measure to prevent encroaching on the space of other shoppers (e.g. Lumpkin et al., 1985; Meneely et al., 2009); and in-store seating areas were needed for those who found shopping a physically difficult activity (e.g. Lambert, 1979; Lumpkin et al., 1985; Mason and Bearden, 1978). Several participants also identified the importance of having a navigable layout since older people can find it difficult remembering where products are located (e.g. Leighton and Seaman, 1997). Other aspects of the physical environment, such as readable store signage (e.g. Lambert, 1979) and quality trolleys/baskets (Pettigrew et al., 2005) further extended the generic definition supplied by Lindquist (1974-1975) to older customers.

The fourth dimension delineated the Atmospheric Environment. In Lindquist's (1974-1975) framework this construct included attributes such as feelings of acceptance, warmth or ease. Here, this was extended to include cleanliness and tidiness, good lighting, pleasant sounds and pleasant smells (see Burt and Gabbott, 1995). Lighting is placed within this category because of the reported perception of several participants that this attribute contributed to their mood, although it is equally possible that mood was influenced by practical impacts of the attribute, such as ease of reading labels: "I get frustrated when I can't see the food properly. I want it to be light and airy. That helps to make me feel more comfortable". This would align more with Lindquist's (19741975) classification of lighting as part of the physical environment.

The inclusion of Pricing and Promotions as separate themes is supported by many classical store image studies (e.g. Kunkel and Berry, 1968; Lindquist, 1974-1975; Samli et al., 1998; Zimmer and Golden, 1988). In the current research these were found to be intertwined concepts with respondents highlighting competitive pricing as a backdrop to a wider range of promotional offerings (e.g. multiple-buy, price discounts, clearance items and loyalty cards). Whilst these have been well documented in a range of studies, the importance of loyalty cards represents a more recent trend in grocery retailing, superseding food stamps (Kunkel and Berry, 1968). Meneely et al. (2009) noted that older people liked to participate in reward schemes and are motivated by the thrill of obtaining a bargain (Myers and Lumbers, 2008).

Services, such as home delivery, returns and additional in-store services (e.g. dry cleaning) have been well documented (e.g. Kunkel and Berry, 1968; Lindquist, 1974-1975). These were all found to be 
applicable to older shoppers (see Appendix), with extensions including the importance of an efficient and fair complaints system (e.g. Lumpkin et al., 1985). One respondent discussed this at length, highlighting that having this assurance reduces purchasing risksomething considered as very important when buying both higher risk products (Moschis, 1992) and perishable items (Hare et al., 1999).

The role of Personnel has resonated as important in many of the classical store image studies (e.g. Kunkel and Berry, 1968; Lindquist, 1974-1975; Samli et al., 1998; Zimmer and Golden, 1988), to include attitude, knowledgeability and the number of service staff. In the current study respondents were more explicit in the properties they considered to represent this component. As such, the importance of friendly, helpful and polite staff was included. Older people are thought to place importance in the retail staff since they offer a further opportunity for interaction and socialising (e.g. Kang and Ridgway, 1996; Myers and Lumbers, 2008).

Martineau (1958) and Lindquist (1974-1975) both highlighted the importance of Clientele as a component of store image. Martineau proposes there to be an element of social class appeal when evaluating a retail store. Respondents discussed feeling more comfortable around other shoppers who were of a likeminded disposition. This was extended to other shoppers that were friendly (e.g. Kang and Ridgway, 1996; Myers and Lumbers, 2008) and helpful when asked to provide assistance, for example, in reaching products or holding doors open: "I definitely need to feel comfortable if asking a fellow shopper for help reaching food from a high shelf or similar".

\subsection{Quantitative research}

Following advice about store image scale construction (Doyle and Fenwick, 1974; Zelnio and Gagnon, 1981) 42 store image attributes were taken forward for quantitative exploration using a selfcompletion survey. Respondents were asked to rate the importance of each of the items when making a store choice decision using a 7-point Likert scale ( $1=$ Extremely Unimportant $-7=$ Extremely Important). An interlocking quota sample was drawn to represent the profile of the over-60 age group within England. Respondents were selected by age, gender and geographical location to encourage a more representative sample. Furthermore only those people who were responsible for doing their household's grocery shopping were eligible to take part.

Overall, 2000 questionnaires were sent out via post. In line with the recommendations provided by Dillman (1978), a twowave procedure was implemented with a reminder postcard sent between send-outs. In total, 356 responses were collected from wave one and 168 responses from wave two; a combined sample response rate of $26.2 \%$. Independent sample $t$-tests verified no statistically significant differences (Armstrong and Overton, 1977). To rectify the small amount of missing data, $(<5 \%)$, the Expectation-Maximization (EM) algorithm was used to impute empty cells (Allison, 2002).

\subsection{Exploratory factor analysis}

Whilst the taxonomy presented as a result of the qualitative analysis provided some insights into the underlying structure of the items, this was provisional and needed empirical testing with more generalizable data. Hence the remaining items were subjected to an exploratory factor analysis (EFA) (DeVellis, 2003).

In the initial analysis the Kaiser-Meyer-Olkin Measure of Sampling Adequacy (KMO) was.936 with Bartlett's test for sphericity significant. The EFA procedure used principal axis factoring with varimax rotation (e.g. Arnold and Reynolds, 2003; Diamantopoulos and Souchon, 1999). A total of seven factors with an eigenvalue of greater than 1.0 were extracted from the data. The seven-factor solution explained $67.41 \%$ of the variance in the observed items. The rotated component matrix highlighted three items with either (1) cross loadings on one or more other factors above .45 or (2) low factor loadings below .45. In line with the advice of Hair et al. (2009), and to preserve the assumption of unidimensionality (Gerbing and Anderson, 1988), 'availability of dietary products', 'accessible bus routes' and 'a quality complaints procedure' were eliminated. The resultant seven-component factorial solution provided an empirically and substantively explainable structure consisting of 39 store image items.

Factor one consisted of items relating to the aesthetics and tangible quality of the store and its components (i.e. shelves, trolleys, etc.), hence it was labelled Store Environment. The selection and quality of products available were strongly referred to in factor two, and was therefore labelled as Merchandise. In factor three each of the items related to the quality of staff within the store; accordingly it was labelled as Personnel. Factor four included the stores pricing policy and application of promotions, as well as the returns policy. This was therefore labelled Pricing \& Promotions. The fifth component consisted of items relating to the type of patron using the store; as such this factor was referred to as Clientele. Factor six included items that related to the characteristics of the store that has little to do with the environment or produce, but included aspects of a stores functional policy such as a delivery service. This factor was labelled as Services. Finally, the items in factor seven referred to the accessibility and convenience of the store; for instance its opening times and car parking provision. This was labelled as Accessibility. This outcome differed very little with the initial framework developed through qualitative analysis. The only significant difference was that the hypothesized atmospheric and physical environmental components were adjoined to make the wider Store Environment construct. This suggests that the importance ascribed by shoppers to both physical and atmospheric aspects of a grocery store were significantly correlated to justify their fusion.

\subsection{Confirmatory factor analysis}

A measurement model, representing the indicators, factors and how they interrelated was specified and estimated (Brown, 2006). In line with Gerbing and Anderson's (1988) advice for assuring unidimensionality, each of the seven factors was integrated into a measurement model and estimated using the Mplus 5.4 Robust Maximum Likelihood (RBL) procedure (Muthen and Muthen, 2009). The parameters for each of the remaining 39 items and their corresponding factors are given in Table 1. Assessment of the model fit statistics suggested a poor initial fit between the model and data with estimates below commonly accepted thresholds $(\mathrm{CFI}=.86 ; \mathrm{TLI}=.85$; RMSEA $=.07)$ ( $\mathrm{Hu}$ and Bentler, 1999). Assessment of the standardised residual estimates identified areas of strain within the measurement model. Further exploration, in the form of Modification Indices (MI), suggested seven items with highly correlated errors (product freshness, different product sizes, spacious layout), cross loading on unspecified factors (good lighting), or low factor loadings (money-off discounts, helpful staff, availability of non-food products).

These issues were substantively explainable (Brown, 2006), all with MI's in excess of 50.0. To retain the internal consistency and (in some cases) the unidimensionality of the scales, all offending items were duly eliminated from the measurement model. A second measurement model was estimated, revealing a more improved fit between the model and data $(\mathrm{CFI}=.91 ; \mathrm{TLI}=.90$; RMSEA $=.07)$. 


\subsection{Construct validity}

As tests of construct validity, both convergent and discriminant validity were assessed. Convergent validity was evident in all seven store image constructs, with all items loading significantly

Table 1

Confirmatory factor analysis.

Standardized factor loadings

(standard errors)

\begin{tabular}{|c|c|}
\hline \multicolumn{2}{|l|}{ Store environment } \\
\hline SE1. Good lighting & - \\
\hline SE2. Spacious layout & - \\
\hline SE3. Quality trolleys \& baskets & $.837(.015)$ \\
\hline SE4. Reachable shelving & $.812(.016)$ \\
\hline SE5. Wide aisles & $.839(.014)$ \\
\hline SE6. Navigable layout & $.847(.014)$ \\
\hline SE7. Clear signage & $.817(.016)$ \\
\hline SE8. Cleanliness and tidiness & $.844(.014)$ \\
\hline SE9. Pleasant smells & $.732(.022)$ \\
\hline SE10. Pleasant sounds & $.578(.030)$ \\
\hline SE11. In-store seating & $.535(.032)$ \\
\hline SE12. Efficient checkouts & $.713(.023)$ \\
\hline \multicolumn{2}{|l|}{ Merchandise } \\
\hline M1. Product freshness & - \\
\hline M2. Product ranges & $.869(.016)$ \\
\hline M3. Product quality & $.775(.021)$ \\
\hline M4. Product availability & $.828(.018)$ \\
\hline M5. Different product sizes & - \\
\hline M6. Branded products & $.583(.032)$ \\
\hline M7. Clear product information & $.588(.032)$ \\
\hline \multicolumn{2}{|l|}{ Personnel } \\
\hline P1. Knowledgeable staff & $.818(.016)$ \\
\hline P2. Available staff & $.908(.009)$ \\
\hline P3. Polite staff & $.953(.006)$ \\
\hline P4. Helpful staff & - \\
\hline P5. Friendly staff & $.945(.006)$ \\
\hline \multicolumn{2}{|l|}{ Pricing $\mathcal{E}$ promotions } \\
\hline PP1. Money-off discounts & - \\
\hline PP2. Multi-buy promotions & $.771(.021)$ \\
\hline PP3. Competitive prices & $.683(.027)$ \\
\hline PP4. Reduced-to-clear items & $.612(.030)$ \\
\hline PP5. Loyalty cards & $.877(.016)$ \\
\hline PP6. Returns policy & $.612(.031)$ \\
\hline \multicolumn{2}{|l|}{ Clientele } \\
\hline C1. Helpful shoppers & $.939(.007)$ \\
\hline C2. Friendly shoppers & $.973(.006)$ \\
\hline C3. Likeminded shoppers & $.879(.011)$ \\
\hline \multicolumn{2}{|l|}{ Services } \\
\hline $\begin{array}{l}\text { S1. Additional services (cafe, key } \\
\text { cutting, etc) }\end{array}$ & $.741(.043)$ \\
\hline S2. Home delivery & $.745(.044)$ \\
\hline S3. Availability of non-food products & - \\
\hline \multicolumn{2}{|l|}{ Accessibility } \\
\hline C1. Store location & $.755(.031)$ \\
\hline C2. Long opening times & $.713(.032)$ \\
\hline C3. Free car parking & $.660(.034)$ \\
\hline
\end{tabular}

$(p<.01)$ and the Average Variance Extracted (AVE) analysis explaining a minimum of $50 \%$ of variance in the observed items (Fornell and Larcker, 1981). Discriminant validity was checked and confirmed as evident at a satisfactory level for all factors (Fornell and Larcker, 1981) (see Table 2). Once the store image scale had been successfully developed, the focus of the analysis evolved to the classification of meaningful and relevant segments (as in Hansen and Deutscher, 1977-1978).

\section{Developing a typology of older shoppers}

A two-stage clustering protocol (Punj and Stewart, 1983) was implemented combining the benefits of both hierarchical and nonhierarchical methods. First the summed scales for each of the store image factors were calculated, and a cluster analysis performed using Ward's (1963) hierarchical method (squared Euclidian distances). A well-established approach was utilised to select an appropriate scope of clusters (Hair et al., 2009), comparing a range of different solutions (in this case 3-6). The selected five-cluster solution was based on interpretation of the dendrogram and agglomeration schedules of the hierarchical cluster process, and further supported through procedures proposed by Sharma (1996). Following this, a non-hierarchical k-means clustering procedure (MacQueen, 1967) was adopted to produce a final solution which used the hierarchical cluster centres as the initial seeds. The clarity and practicality of the shopping types derived was assessed and a solution proposed which allocated subjects to five clusters $(N 1=152, N 2=120, N 3=98, N 4=84$ and $N 5=70)$.

The internal validity of the solution was subsequently tested by procedures prescribed by Klastorin (1983) and Westbrook and Oliver (1991). Firstly, canonical discriminant analysis showed $94.5 \%$ of original grouped cases were correctly classified, and secondly, a two-dimensional scatter-plot of the clusters revealed that the clusters occupied distinct positions. Further internal validity was indicated through performing a multivariate analysis of variance (MANOVA) where the five clusters were compared using the remaining 39 store items rather than the 7 identified factors. This produced a significant result (Hotelling's Trace $=2.962 ; F=16.713, p<.001)$ indicating that the five segments differed significantly from each other. In addition, separate univariate ANOVA for the same 39 items all produced significant results at $p<.001$. Taking these results together suggests strong support for the internal validity of the resultant five-cluster solution. Several methods for assessing external validity are available to researchers (e.g. Ivens and Valta, 2012), although this study utilises an approach recently executed by Schoefer and Diamantopoulos (2009). This requires that a theoretically relevant variable that is not used in the derivation of the cluster solution is compared across segment membership. Where such a variable can be shown to be impacted on by a typology, then the classification will have explanatory value. In this instance the value of older shopper types for retailers and store attribute researchers would be enhanced if the clusters were strongly aligned to shopper

Table 2

Factor correlation matrix

\begin{tabular}{|c|c|c|c|c|c|c|c|}
\hline & 1 & 2 & 3 & 4 & 5 & 6 & 7 \\
\hline 1. Store environment & $.58(.76)$ & & & & & & \\
\hline 2. Merchandise & .42 & $.55(.74)$ & & & & & \\
\hline 3. Personnel & .74 & .31 & $.89(.94)$ & & & & \\
\hline 4. Pricing \& promotions & .67 & .34 & .58 & $.52(.72)$ & & & \\
\hline 5. Clientele & .40 & .16 & .41 & .43 & $.87(.93)$ & & \\
\hline 6. Services & .34 & .23 & .27 & .45 & .37 & $.55(.74)$ & \\
\hline 7. Accessibility & .53 & .39 & .43 & .53 & .34 & .37 & $.51(.71)$ \\
\hline
\end{tabular}

Note: lower segment=factor correlations; diagonal $=$ AVE $(\sqrt{ }$ AVE $)$. 
satisfaction (Ivens and Valta, 2012). This variable has also generally been regarded as having different mean levels across identified shopper types (see Theodoridis and Chatzipanagiotou, 2009). A multiple item composite taken from the scale introduced by Fornell (1992) to reflect overall store satisfaction was used to measure this. A one-way ANOVA test for satisfaction as the dependent variable using cluster membership as the fixed factor produced a highly significant outcome $(F=13.005 ; p<.001)$, providing support for the external validity of the solution.

The final five-cluster solution presented in Table 3 describes the segments based on the mean scores for each of the 7 factors used to derive the segments and the additional satisfaction variable. To improve the practical implications, or external validity, of the solution, a series of other personal characteristic and behavioural variables were included. This is to aid practitioners in better reaching the target audience-i.e. older shoppers-and has been used in many previous studies; e.g. Arnold and Reynolds (2003), Ivens and Valta (2012), Megicks et al. (2012).

The first segment, given the label prudent neutrals and comprising $29 \%$ of the sample, is the largest of the five clusters. These shoppers appear to be fairly neutral, when compared to other segments, on most aspects of the store, with the exception of Price \& Promotions; they also attach some importance to the Services factor. This suggests that segment one is a more cautious group in regard to the cost of grocery shopping and its members therefore place a high emphasis on prices, scoring this higher than any of the other clusters. They may also see the potential value available through the additional services (e.g. delivery) on offer compared with other groups. The scores for Personnel and Accessibility, although lower in comparison with some other segments, are nonetheless highly important factors for these shoppers. The mean satisfaction score for this group is below the average for all older shoppers, and significantly lower than the two most satisfied segments. The prudent neutrals have demographic characteristics and patterns of shopping behaviour that are very closely associated with the average older shopper in the sample as a whole, with little variation being displayed except in the case of working status. This segment has the highest proportion (25\%) of its members in employment, which is significantly greater than some of the other groups.

The second segment is entitled all-round demanders (23\% of the total sample) owing to the high importance they place on all aspects of the shopping experience including Services. They score highest on the Store Environment, Personnel, Clientele, Services and Accessibility and are only marginally lower than the topscoring groups on the remaining two factors Merchandise and

Table 3

Older grocery shopper types.

\begin{tabular}{|c|c|c|c|c|c|c|c|c|}
\hline Cluster (type) & $\begin{array}{l}1 \text { (Prudent } \\
\text { neutrals) }\end{array}$ & $\begin{array}{l}2 \text { (All-round } \\
\text { demanders) }\end{array}$ & $\begin{array}{l}3 \text { (Reluctant } \\
\text { casuals) }\end{array}$ & $\begin{array}{l}4 \text { (Demanding } \\
\text { sociables) }\end{array}$ & $\begin{array}{l}\mathbf{5} \text { (Affluent } \\
\text { utilitarians) }\end{array}$ & Total & & \\
\hline No (\%) & $152(29)$ & $120(23)$ & 98 (19) & $84(16)$ & $70(13)$ & $\begin{array}{l}524 \\
(100)\end{array}$ & $\left(F\right.$ value $\left./ \chi^{2}\right)$ & $\begin{array}{l}\text { Multiple comparison } \\
\text { (significant at } p<.05 \text { ) }\end{array}$ \\
\hline \multicolumn{9}{|l|}{ Store image factor } \\
\hline Store environment & 5.97 & 6.57 & 5.47 & 6.32 & 5.26 & 5.97 & $54.36^{* * *}$ & $\begin{array}{l}1>3,1>5,2>1,2>3,2>5 \\
4>1,4>3,4>5\end{array}$ \\
\hline Merchandise & 5.91 & 6.43 & 5.37 & 6.22 & 6.55 & 5.95 & $36.53^{* * *}$ & $\begin{array}{l}1>3,2>1,2>3,2>5,4>1, \\
4>3,4>5,5>3\end{array}$ \\
\hline Personnel & 6.25 & 6.68 & 5.88 & 6.61 & 5.29 & 6.21 & $47.46^{* * *}$ & $\begin{array}{l}1>3,1>5,2>1,2>3,2>5 \\
3>5,4>1,4>3,4>5\end{array}$ \\
\hline Pricing \& promotions & 6.33 & 6.25 & 4.62 & 5.58 & 4.44 & 5.32 & $73.90^{* * *}$ & $\begin{array}{l}1>3,1>5,2>1,2>3,2>4 \\
2>5,4>3,4>5\end{array}$ \\
\hline Clientele & 4.60 & 6.15 & 4.57 & 5.85 & 1.95 & 4.80 & $342.92^{* * *}$ & $\begin{array}{l}1>5,2>1,2>3,2>5,3>5, \\
4>1,4>3,4>5\end{array}$ \\
\hline Services & 4.27 & 5.53 & 2.05 & 1.95 & 2.45 & 3.53 & $385.16^{* * * *}$ & $\begin{array}{l}1>3,1>4,1>5,2>1,2>3 \\
2>4,2>5,5>4,5>3\end{array}$ \\
\hline Accessability & 6.05 & 6.59 & 5.31 & 6.30 & 5.41 & 5.99 & $35.39^{* * *}$ & $\begin{array}{l}1>3,1>5,2>1,2>3,2>5 \\
4>3,4>5\end{array}$ \\
\hline Satisfaction & 5.49 & 6.04 & 5.27 & 5.91 & 5.37 & 5.62 & $13.05^{* * *}$ & $\begin{array}{l}2>1,2>3,2>5,4>1,4>3 \\
4>5\end{array}$ \\
\hline \multicolumn{9}{|l|}{ Demographics and behaviour } \\
\hline Gender (\% women) & 60 & 69 & 59 & 63 & 61 & 62 & 3.23 & \\
\hline $\begin{array}{l}\text { Household composition } \\
\quad(\% \text { couples })\end{array}$ & 53 & 48 & 51 & 54 & 57 & 52 & 1.53 & \\
\hline Mobility (\% with cars) & 77 & 64 & 74 & 76 & 84 & 75 & $10.87^{*}$ & \\
\hline Age $(\%$ under 70$)$ & 47 & 45 & 50 & 39 & 49 & 46 & 2.42 & \\
\hline Education (\% no qualifications) & 42 & 56 & 38 & 46 & 29 & 43 & $15.51^{* *}$ & \\
\hline Income (\% under $£ 15,000)$ & 51 & 69 & 44 & 56 & 39 & 53 & $14.28^{* * *}$ & \\
\hline Working status (\% employed) & 25 & 15 & 22 & 12 & 20 & 20 & 8.13 & \\
\hline $\begin{array}{l}\text { Geodemographic area } \\
\quad \text { (\% comfortable or better) }\end{array}$ & 68 & 52 & 71 & 66 & 77 & 66 & $16.26^{* *}$ & \\
\hline Household ownership (\% owning) & 82 & 68 & 81 & 85 & 87 & 80 & $13.88^{* *}$ & \\
\hline $\begin{array}{l}\text { Frequency of shopping } \\
\quad \text { (\% shopping }>4 \text { times a month) }\end{array}$ & 47 & 49 & 50 & 60 & 41 & 49 & 5.49 & \\
\hline $\begin{array}{l}\text { Distance from store (\% travelling less } \\
\text { than } 2 \text { miles) }\end{array}$ & 56 & 60 & 56 & 65 & 51 & 58 & 3.53 & \\
\hline Shopping at main store (\%) & 78 & 79 & 74 & 80 & 77 & 78 & 1.58 & \\
\hline $\begin{array}{l}\text { Expenditure on shopping } \\
\quad \text { (\% spending }>£ 50 \text { per week) }\end{array}$ & 41 & 43 & 40 & 44 & 46 & 43 & .77 & \\
\hline
\end{tabular}

Highest scores in bold; lowest in italics.

Significance:

$* * * *<.001$

$* * p<.01$.

$* p<.05$. 
Price \& Promotions. This group is the highest scoring of all the segments in terms of satisfaction with their chosen store. Particular demographic characteristics distinguish the all-round demanders from other segments; notably they are the least well-off as indicated by having the highest proportion earning less than $£ 15,000$ p.a. and the weakest geodemographic area indicator; they also have the lowest proportion owning their own property. Furthermore there are proportionately more women in this segment than any other, many of whom live on their own. This group has the lowest level of educational qualifications and the lowest level of mobility in terms of car ownership.

Representing $19 \%$ of the total sample, reluctant casuals place low levels of importance on most of the store image factors in comparison with the other segments. Members of this group score lowest for Merchandise and Accessibility; they also have a very low score for Services. The reluctant casuals have the lowest satisfaction score of all the identified segments. In terms of its demographic profile this segment has the highest proportion of men and the highest proportion of members aged less than 70 years; they are the second lowest group in regard to the number being in households without partners. This group has a relatively low proportion without any qualifications and is the second highest group in terms of income; this is likely to be associated with an above average proportion being in employment. The geodemographic measure also indicates that there is a large proportion living in more well-off areas. Of all the segments they have the fewest members spending more than $£ 50$ per week, and the lowest percentage on average of shopping being undertaken at the main store. It appears that this segment do not place great importance on the shopping experience generally and are reluctant grocery shoppers who do not fully engage with the activity at any level.

Demanding Sociables represent $16 \%$ of the total sample. They are characterised by placing a generally high level of importance on all store image factors except Services which is not at all important to members of this segment. Beyond that it is difficult to distinguish between the factors that they perceive as important as they are demanding at all levels, although Personnel, in particular relating to the benefits provided by staff at the store, is of key importance. Together with a high score on Clientele compared with most other segments this group appears to be strongly influenced by the role that sociality plays in their wider evaluations of the shopping experience. This can, in part, be explained by the demographic and behavioural profile of this group which shows that they tend to live closer to their store, visit on a more frequent basis, and undertake a larger proportion of their shopping at their mainly frequented store than other segments; they also have a high level of satisfaction with that store. Compared with other segments, the demanding sociables are older with the largest proportion of over70s and has the lowest proportion of its members in employment.

The final cluster, accounting for $13 \%$ of all respondents, is named as the affluent utilitarians, and is the smallest of all the identified groups. These shoppers are very focused on the Merchandise factor with the highest score for this across all the groups. In addition they do not place a great deal of importance on a number of other factors relative to other segments including the Store Environment, Personnel, and Clientele. They are also not price conscious with the lowest score for Price \& Promotions being displayed in this cluster. The social and aesthetic aspects of grocery shopping therefore appear to be of limited importance whereas the functional dimension relating to merchandise characteristics is predominant amongst these shoppers. Their satisfaction levels are relatively low in comparison with most other groups having the second lowest average score of all the segments. The demographics of affluent utilitarians suggest that they are better off than the rest of the segments in terms of where they live, income and home ownership. They also have the highest standing of all the groups in relation to educational qualifications. This segment has a high proportion of younger (under 70 years) members, and the highest proportion of people living in households as couples; they are the most mobile group as depicted by the percentage owning cars. The shopping behaviour of this segment has the highest proportion of its members spending more than $£ 50$ per week, but the lowest proportion shopping more than four times a month, thus indicating fewer shopping trips with bigger spending on each occasion; in undertaking this they generally travel further than members of the other segments.

\section{Discussion and implications}

The research presented here sets out to sub-divide and classify older grocery shoppers based upon the different levels of importance that they give to various store image factors when deciding on store choice. In so doing a newly validated store image scale is developed that specifically relates to older customers in a contemporary grocery shopping context, which is utilised as the basis for distinguishing between the different types of shopper. Additional demographic and behavioural characteristics of these shoppers were employed to profile the identified segments. The study presents five shopper types within the broad over-60s age classification of older shoppers that can be used for further understanding behaviour across this increasingly important group of consumers, and as a means for developing appropriately targeted retail marketing strategies.

\subsection{Implications for research}

This study provides an empirical investigation of the differences in shopping requirements across the older shopper sector. It identifies a set of homogenous, but clearly distinctive, groups within this particular segment of the market based upon the importance of store image factors in store choice decision-making. It further develops understanding of variations in shopper requirements, demographics and behaviour in an age-based market sector, and offers a timely contrast to work undertaken at the other end of the age spectrum over a number of years (Breazeale and Lueg, 2011; Sprotles and Kendall, 1986) in which shopping typologies of teenagers are proposed. In line with this, the contribution of the research presented here gives a specific focus to the wide-ranging differences that may exist between consumers that are often labelled as a homogeneous demographic with standardized requirements and behaviours (see $\mathrm{Hu}$ and Jasper, 2007). In reality findings indicate that, far from being the same, a complex set of needs lead to differences in requirements being sought through various aspects of the retail offer within these groupings. Building on this, and consistent with previous research (e.g. Westbrook and Black, 1985), this study develops the theme of differences in emphasis given to store image factors by shoppers in making store choice decisions. In particular it extends the generally accepted and long-standing understanding that people shop for different reasons (Tauber, 1972), and that their motivations are translated into various demands in terms of what the retail outlet offers by way of being able to a meet a specific shopper's requirements. As part of this, within the older age group as a whole, differences in the circumstances of individuals affect their preferences particularly with regard to the role that shopping plays in their lives from a social viewpoint, in contrast with the utilitarian perspective of acquiring food and groceries for consumption purposes (Babin et al., 1994). Amongst older shoppers this is of specific interest, as past research has shown that the sociality of the shopping experience is more prevalent for those people of an older age, particularly those living alone and therefore seeking social interaction to overcome 
loneliness and boredom, and fulfilling other benefits such as taking exercise and getting a change of scenery (e.g. Kim et al., 2005; Myers and Lumbers, 2008; Sudbury and Simcock, 2009).

The differences in these reasons for shopping amongst older consumers, together with personal characteristics are reflected in the typologies developed in this research. Some shoppers afford great importance to the socially-based image factors when making store choice decisions, whereas others do not, and give greater emphasis to factors associated with the functional dimension of grocery shopping. Thus the demanding sociables and the all-round demanders place great importance on Clientele and Personnel, whilst for the affluent utilitarians the importance of these two factors is not weighted so highly in their decision making. Affluent utilitarians place a very strong emphasis on the Merchandise factor which indicates this group's concern for the products on offer and how their attributes contribute to the functionality of their use and the shopping experience. Furthermore, prudent neutrals place only limited emphasis on Clientele, although they regard Personnel as being very important; but they afford the greatest importance to Price \& Promotions thus distinguishing them from other groups. The reluctant casuals similarly score low on Clientele and are relatively low scoring on the importance of Personnel, which reflects generally on their comparative dislike of grocery shopping from both social and functional perspectives.

A further, but extremely important, contribution of this research is the identification of a store image scale comprising a set of factors that specifically reflect the importance in store choice decisions of older shoppers. This scale extends store image research by providing contemporary insights into the specific requirements of older shoppers in a changing retail environment with evolving market conditions. Thus the inclusion of a new factor relating to Clientele as part of a reliable and valid scale broadens the conceptualisation of store image to account for 'other shoppers', which although consistent with previous understanding of the needs of older shoppers (Kang and Ridgway, 1996), may also hold credence for shoppers in general. The work provides greater clarification that generic store image scales may lack validity when applied with specific groups of consumer, and that researchers should be cognisant to the potential need for extension.

\subsection{Implications for retail practice}

The importance of an expanding older shopper sector for retailers and suppliers in the grocery industry cannot be ignored, and distinguishing variations in customer types provides insights which can be levered for future success. Moreover the combination of store image, demographic and shopping behaviour in the segmentation process facilitates the formulation of appropriate merchandising and retail service strategies. Although in some instances there do not appear to be dramatic differences between segments they are significant in many respects, and therefore provide a platform for differentiating the retail mix where appropriate from an economic cost and return standpoint.

Clearly there are opportunities for independent retailers to exploit explicit differences in store image requirements by formulating a targeted retail positioning that focuses on the specific demands of particular segments (e.g. Merchandise for the affluent utilitarians or Price \& Promotions for the prudent neutrals). Yet there is also potential in a broader offer that encompasses the range of expectations held by the two segments that look to fulfil a wider range of needs through their grocery shopping (the all-round demanders and the demanding sociables), with a distinction being made around the greater emphasis on the importance of Services for the former group. Moreover, whilst it appears possible to propose a specific retail offer that accounts for the differing degrees of importance afforded to the store image factors by the reluctant casuals (such as a diminished emphasis on Services), this may not be a viable strategy given the reticence of this group to fully engage with the grocery shopping experience.

Alternatively smaller retailers and producers may pay specific attention to individual segments within the older shopper sector and focus their efforts on the high scoring aspects the older consumers retail offer generally (Merchandise, Personnel, Store Environment, and Accessibility) as well as those that clearly distinguish between the needs of particular groups (Price \& Promotions, Clientele, Services, and Accessibility). Further to this there are possibilities for larger retail multiples to develop an all-encompassing retail strategy that accommodates the needs of older shoppers generally or a well-considered approach that creates a distinction between their sub-brands to meet the requirements of the different shopper types.

The degree to which grocery retailers and manufacturers encompass a targeted approach to older shopper groups is dependent upon the extent to which they can either focus or differentiate within this sector. Variations in levels of satisfaction across the groups adds a further dimension to the shaping of the retail offer in the context of different older grocery shopping types.

\subsection{Limitations and future research}

This study has a number of limitations which signpost directions for further investigation. The generalisability of the findings beyond the UK grocery sector is not possible and further research of older shoppers in different product and geographical markets is required to validate its applicability in these settings. Responses elicited in the quantitative study only relate to a single chosen store which in practice may not be a true reflection of actual shopper behaviour. Indeed many older shoppers may frequent multiple stores as part of their regular grocery shopping activities, and this could be regarded as an important part of the social interaction that they seek offering multiple interactions with staff and other shoppers. Further research of this would give deeper understanding of how different shoppers' needs are fulfilled in this respect perhaps through adopting a 'servicescapes' perspective (Bitner, 1992).

Older shoppers may use alternative sources of acquiring produce not explored in this study, such as on-line ordering and home delivery. Research into shopping through internet channels may be timely as its adoption increases, older consumers become more familiar with this mode of shopping, and grocery retailers expand their on-line services. Such insights may broaden and deepen the nature of the typologies that have been developed.

The use of cross-sectional data in a single context does not account for the possibility of older shoppers moving across groups over time as they grow older and their circumstances change, which a longitudinal investigation may identify. Further research could also extend the work by, for example, Carstensen (2006), Labouvie-Vief (2009), and Sudbury and Simcock (2009), which accommodates characteristics of older consumers not considered in this research particularly those of a socio-psychological nature such as attitudes, personality and emotional responses, but could integrate these with store attributes to further profile the existing segments or as a platform for undertaking a different segmentation approach. In addition opportunities for future research exist through utilising the older shopper store image scale to enhance understanding of behaviour in the sector. Within the groups of shopping types relationships between the different store image factors and such outcomes as customer retention, loyalty, as well as satisfaction could be identified, thus offering insights for retailers to improve their performance against these measures. Finally research amongst stores and suppliers into whether and how they address differences in their older shopper segments, and the effectiveness of strategies adopted in this regard offers an alternative avenue of investigation of an increasingly more important sector of contemporary retailing. 
Table A1

Dimensional attributes of store choice.

\begin{tabular}{|c|c|c|}
\hline Dimension/attribute & Illustrative quote & Older consumer specific literature (e.g.) \\
\hline \multicolumn{3}{|l|}{ Accessibility } \\
\hline Store location & $\begin{array}{l}\text { "Convenience is definitely a big point. I can't get to other stores that easily. I am happy as long as } \\
\text { it is nearby to me." (R10) }\end{array}$ & Burt and Gabbott (1995), Meneely et al. (2009) \\
\hline Bus access & "Gosh, the buses are vital for me. It would be very difficult for me otherwise..." (R8) & Hare et al. (1999), Meneely et al. (2009) \\
\hline Car parking & $\begin{array}{l}\text { "The availability of spaces in the car park is essentially very important to me. I need to get close } \\
\text { to the store." (R29) }\end{array}$ & $\begin{array}{l}\text { Goodwin and Mcelwee (1999), Meneely et al. } \\
\text { (2009) }\end{array}$ \\
\hline Long opening times & $\begin{array}{l}\text { "The shops are forever open. They are always open until gone eight. That to me, is very } \\
\text { important because I am always going to places and then coming back and realising I need } \\
\text { something." (R15) }\end{array}$ & \\
\hline \multicolumn{3}{|l|}{ Merchandise } \\
\hline Branded products & $\begin{array}{l}\text { "I like a name. When a product is branded, you know what you are getting. They have a name to } \\
\text { it, and they then keep their standard up." (R13) }\end{array}$ & Lumpkin et al. (1985), Meneely et al. (2009) \\
\hline Product freshness & $\begin{array}{l}\text { "If its fresh products it has to be ripe and not flagging. If its meat it has got to be the right smell } \\
\text { and colour." (R28) }\end{array}$ & Goodwin and Mcelwee (1999) \\
\hline $\begin{array}{r}\text { Clear product } \\
\text { information }\end{array}$ & $\begin{array}{l}\text { "I don't like surprises in prices, ingredients and the like. Make sure the labels are clear and easy } \\
\text { to read for older people" (R4) }\end{array}$ & Lambert (1979), Meneely et al. (2009) \\
\hline Product availability & $\begin{array}{l}\text { "It's annoying when you go for something that you always have had, and it's one of the reasons } \\
\text { that we go there, and they take it away! So frustrating." (R6) }\end{array}$ & Hare et al. (1999), Pettigrew et al. (2005) \\
\hline Product quality & $\begin{array}{l}\text { "Top of my list is quality. I really believe that it is the quality of what you eat that is important. } \\
\text { Quality is foremost...you must put quality into your body to be quality yourself." (R30) }\end{array}$ & $\begin{array}{l}\text { Burt and Gabbott (1995) Goodwin and Mcelwee } \\
\text { (1999), Hare et al. (1999) }\end{array}$ \\
\hline Product ranges & $\begin{array}{l}\text { "The most important thing for me is that they have what I want-everything I need for each } \\
\text { day." (R36) }\end{array}$ & $\begin{array}{l}\text { Burt and Gabbott (1995), Lumpkin, 1985, } \\
\text { Meneely et al. (2009) }\end{array}$ \\
\hline Different product sizes & "I don't always want big sizes for the families. Small containers!" (R1) & $\begin{array}{l}\text { Hare et al. (2001), Lambert (1979), Lumpkin } \\
\text { et al. (1985), Meneely et al. (2009) }\end{array}$ \\
\hline Dietary ranges available & $\begin{array}{l}\text { "I am a diabetic so I need to regulate what I eat. I need to have a healthy diet through a range of } \\
\text { products!" (R9) }\end{array}$ & $\mathrm{N} / \mathrm{A}$ \\
\hline
\end{tabular}

Physical environment

Reachable shelving

Wide aisles

In-store seating

Navigable layout

Spacious layout

Clear signage

Efficient checkouts

Quality trolleys \& baskets

Atmospheric environment

Cleanliness and

tidiness

Good lighting

Pleasant sounds

Pleasant smells

Pricing $\mathcal{E}$ promotions

Competitive prices

Multi-buy promotions

Money-off discounts

Loyalty cards

Reduced-to-clear

items

Services

Additional facilities

(toilets, key cutting,

etc.

Complaints system

Home delivery

Returns policy

Availability of non-

food items

Personnel

Available staff

Friendly staff
"Convenience is definitely a big point. I can't get to other stores that easily. I am happy as long as Burt and Gabbott (1995), Meneely et al. (2009) "is nearby to me." (R10)

(Ris

"I like a name. When a product is branded, you know what you are getting. They have a name to Lumpkin et al. (1985), Meneely et al. (2009)

it, and they then keep their standard up." (R13)

and colour." (R28)

"I don't like surprises in prices, ingredients and the like. Make sure the labels are clear and easy Lambert (1979), Meneely et al. (2009)

to read for older people" (R4)

"It's annoying when you go for something that you always have had, and it's one of the reasons Hare et al. (1999), Pettigrew et al. (2005)

(R6)

Quality is foremost... you must put quality into your body to be quality yourself." (R30)

(1999), Hare et al. (1999)

Meneely et al. (2009)

Hare et al. (2001), Lambert (1979), Lumpkin N/A

products!" (R9)

"I'm not short, but I have shrunk two inches. We all shrink. The top shelves are sometimes a bit Meneely et al. (2009)

high for people to reach." (R26)

"Having a man in a wheelchair with me I need to have the room to move around. Enough space Lumpkin et al. (1985), Meneely et al. (2009)

for accommodating wheelchairs is important." (R5)

"I need a break often at the end of my trip, or sometimes during..." (R2)

Lambert (1979), Lumpkin et al. (1985), Mason

and Bearden (1978), Meneely et al. (2009)

"The important thing is that I know where things are and that I can get to them easily." (R26) Leighton and Seaman (1997)

"I like it when it is spread out better. When the aisles are wider then it gives the impression of Meneely et al. (2009)

freshness. I don't like it when it is cramped. It feels better when it is open." (R31)

"I think there is a lot to learn when pricing things. When the food is stocked on the shelves it is Lambert (1979)

hard to actually find out how much it is. There are times when prices are not displayed

effectively at all." (R27)

"We like to get through the till pretty quickly." (R6)

"When you are old and you don't want that much stuff, you don't need an enormous big

Lambert (1979), Meneely et al. (2009)

Pettigrew et al. (2005)

"The one thing that I need is store cleanliness. I just need it to be neat, tidy and clean. There "have Burt and Gabbott (1995), Hare et al. (1999)

been times when I have dropped into places and it just doesn't look good." (R28)

"It has to be light! It's depressing going to a dull store!" (R29)

"If it is the right noise, I am comfortable and happy." (R9)

"In the same regard that I need the shop to be clean...it can't smell either." (R23)

Burt and Gabbott (1995)

Burt and Gabbott (1995)

Burt and Gabbott (1995)

"You have to watch the price of things. We are not poor, but you still have to be careful." (R29) Meneely et al. (2009), Lambert (1979)

"If they are selling three for two or BOGOF and I use it then I will buy it." (R26)

"I prefer money off to be honest. Very often they put money off from products that I wouldn't use-Goodwin and Mcelwee (1999)

they don't think of us you see! Getting cash off makes me feel good about what I buy." (R30)

"I like collecting points and getting something for nothing" (R8)

"One of the most exciting parts of the shopping trip is going to the reduction counter." (R11)

Lumpkin et al. (1985)

Hare et al. (1999)

"It is really handy to be able to pick up dry cleaning at the same time as getting my groceries. Talk

about two birds and one shot." (R24)

"If you have a complaint then they need to deal with it. I don't want to be fobbed off with excuses if Lumpkin et al. (1985) they appear not to be interested or whatever!" (R8)

“... a big push towards a greater delivery service...If I cannot move around easily any longer then I Meneely et al. (2009), Lambert (1979) would be happy to use the internet for ordering things." (R18)

"I like to take things back. It's reassuring you see. With oranges and things you obviously cannot see how good they are. Taking them back, you obviously want something to be done about it. "(R4)

"You can get your clothes, cards, and everything else there. All under one roof. That is very important to me now." (R13)
Lumpkin et al. (1985)

Thompson and Thompson (2009) 
Table A1 (continued)

\begin{tabular}{|c|c|c|}
\hline Dimension/attribute & Illustrative quote & Older consumer specific literature (e.g.) \\
\hline Helpful staff & "You really need the staff to be helpful, and not look put out when you ask them for help!" (R13) & $\begin{array}{l}\text { Pettigrew et al. (2005), Leventhal (1997), } \\
\text { Goodwin and Mcelwee (1999), Hare et al. } \\
\text { (1999) }\end{array}$ \\
\hline Knowledgeable staff & "They always know the type of food I like and will advise me. That is important to me." (R4) & Johnson-Hillery et al. (1997) \\
\hline Polite staff & "I expect people to be polite. I expect them to acknowledge me as a person." (R22) & Hare et al. (1999) \\
\hline \multicolumn{3}{|l|}{ Clientele } \\
\hline Friendly shoppers & $\begin{array}{l}\text { "It has to be sociable. I live on my own. I come down; I have a cup of coffee and a chat. I meet my } \\
\text { friends...it can take half an hour or three hours depending on whom I actually meet." (R1) }\end{array}$ & Pettigrew et al. (2005), Hare et al. (1999) \\
\hline Helpful shoppers & $\begin{array}{l}\text { "I am not going to shop in a place where I feel uncomfortable having to ask other shoppers for a } \\
\text { hand." (R1) }\end{array}$ & Pettigrew et al. (2005), Meneely et al. (2009) \\
\hline Likeminded shoppers & $\begin{array}{l}\text { "I think it is to do with the other shoppers'. XXX, for example, I find a little bit off-putting. It's an } \\
\text { awful thing to say, but it's true!" (R34) }\end{array}$ & Pettigrew et al. (2005) \\
\hline
\end{tabular}

\section{Appendix}

See Table A1.

\section{References}

Ahmad, R., 2002. The older or ageing consumers in the UK are they really that different? International Journal of Market Research 44 (3), 337-360.

Allison, P.D., 2002. Missing Data. Sage Publications, London.

Angell, R.J., Megicks, P., Memery, J., Heffernan, T., Howell, K.E., 2012. Discovering the older shopper: a behavioural typology. Journal of Retailing and Consumer Services 19 (2), 259-269.

Armstrong, J.S., Overton, T.S., 1977. Estimating nonresponse bias in mail surveys. Journal of Marketing Research 14 (3), 396-402.

Arnold, M.J., Reynolds, K.E., 2003. Hedonic shopping motivations. Journal of Retailing 79 (2), 77-95.

Babin, B.J., Darden, W.R., Griffin, M., 1994. Work and/or fun: measuring hedonic and utilitarian shopping value. Journal of Consumer Research 20 (4), 644-656.

Bearden, W.O., Mason, J.B., 1979. Elderly use of in-store information sources and dimensions of product satisfaction/dissatisfaction. Journal of Retailing 55 (1), 79-91.

Bellenger, D.N., Robertson, D.H., Greenberg, B.A., 1977. Shopping center patronage motives. Journal of Retailing 53 (2), 29-38.

Bellenger, D.N., Korgaonkar, P.K., 1980. Profiling the recreational shopper. Journal of Retailing 56 (3), 77-92.

Bitner, M., 1992. Servicescapes: the impact of physical surroundings on customers and employees. Journal of Marketing 56 (2), 57-71.

Breazeale, M., Lueg, J.E., 2011. Retail shopping typology of American teens. Journal of Business Research 64 (6), 565-571.

Brown, T.A., 2006. Confirmatory Factor Analysis For Applied Research. Guilford Press, New York, NY.

Burt, S., Gabbott, M., 1995. The elderly consumer and non-food purchase behaviour. European Journal of Marketing 29 (2), 43-57.

Buttle, F., 1985. Measuring food store image using kelly's repertory grid. Service Industries Journal 5 (1), 79-89.

Canabal, J.E., 2002. Decision making styles of young south Indian consumers: an exploratory study. College Student Journal 36 (1), 12-19.

Carstensen, L.L., 2006. The influence of a sense of time on human development. Science 312 (5782), 1913-1915.

Chase, M., Driscoll, L., Stewart, D., Hayhoe, C., Leech, I., 2007. Exploring the relationship of first-year, first-semester college students' mind styles and their consumer decision-making styles. Journal of Family and Consumer Sciences Education 25 (1), 10-23.

Chaston, I., 2011. Older consumer opportunities: small firm response in a selected group of UK service sector markets. Service Industries Journal 31 (3), 371-384.

Churchill, G.A., 1979. A paradigm for developing better measures of marketing constructs. Journal of Marketing Research 16 (1), 64-73.

Cresswell, J.W., 2002. Research Design: Qualitative, Quantitative and Mixed Methods Approaches. Sage Publications, London.

Darden, W.R., Reynolds, F.D., 1971. Shopping orientations and product usage rates. Journal of Marketing Research 8 (4), 505-508.

Darden, W.R., Ashton, D., 1975. Psychographic profiles of patronage preference groups. Journal of Retailing 50 (4), 99-112.

DeVellis, R.F., 2003. Scale Development: Theory and Applications, Second ed. Sage Publications, Thousand Oaks, CA.

Diamantopoulos, A., Souchon, A.L., 1999. Measuring export information use: scale development and validation. Journal of Business Research 46 (1), 1-14.

Dickson, J., Albaum, G., 1977. A method for developing tailormade semantic differentials for specific marketing content areas. Journal of Marketing Research 14 (2), 87-91.
Dillman, D.A., 1978. Mail and Telephone Surveys: The Total Design Method. John Wiley \& Sons, New York, NY.

Doyle, P., Fenwick, I., 1974. How store image affects shopping habits in grocery chains. Journal of Retailing 50 (4), 39-52.

Fan, J.X., Xiao, J.J., 1998. Consumer decision-making styles of young-adult Chinese The Journal of Consumer Affairs 32 (2), 275-294.

Fornell, C., 1992. A national customer satisfaction barometer: the Swedish experience. Journal of Marketing 56 (1), 6-21.

Fornell, C., Larcker, D.F., 1981. Evaluating structural equation models with unobservable variables and measurement error. Journal of Marketing Research 18 (1), 39-50.

Ganesh, J., Reynolds, K.E., Luckett, M.G., 2007. Retail patronage behavior and shopper typologies: a replication and extension using a multi-format, multimethod approach. Journal of the Academy of Marketing Science 35 (3) 369-381.

Gerbing, D.W., Anderson, J.C., 1988. An updated paradigm for scale development incorporating unidimensionality and its assessment. Journal of Marketing Research 25 (2), 186-192.

Goodwin, D.R., Mcelwee, R.E., 1999. Grocery shopping and an ageing population: research note. International Review of Retail, Distribution and Consumer Research 9 (4), 403-409.

Guiot, D., Roux, D., 2010. A second-hand shoppers' motivation scale: antecedents, consequences, and implications for retailers. Journal of Retailing 86 (4), 355-371.

Gunter, B., 1998. Understanding the Older Consumer. Routledge, London, UK.

Hair Jr., J.F., Black, W.C., Babin, B.J., Anderson, R.E, 2009. Multivariate Data Analysis, Seventh ed. Prentice Hall, Upper Saddle River, NJ.

Hansen, R.A., Deutscher, T., 1977-1978. An empirical investigation of attribute importance in retail store selection. Journal of Retailing 53 (4), 59-73.

Hare, C., Kirk, D., Lang, T., 1999. Identifying the expectations of older food consumers: more than a "shopping list" of wants. Journal of Marketing Practice: Applied Marketing Science 5 (6/7/8), 213-232.

Hare, C., Kirk, D., Lang, T., 2001. The food shopping experience of older consumers in Scotland: critical incidents. International Journal of Retail \& Distribution Management 29 (1), 25-40.

Hartman, K.B., Spiro, R.L., 2005. Recapturing store image in customer-based store equity: a construct conceptualization. Journal of Business Research 58 (8), $1112-1120$.

Hu, L., Bentler, P., 1999. Cutoff criteria for fit indexes in covariance structure analysis: conventional criteria versus new alternatives. Structural Equation Modeling 6 (1), 1-55.

Hu, H., Jasper, C.R., 2007. A qualitative study of mall shopping behaviors of mature consumers. Journal of Shopping Centre Research 14 (1), 17-38.

Ivens, B., Valta, K., 2012. Customer brand personality perception: a taxonomic analysis. Journal of Marketing Management 28 (9/10), 1062-1093.

James, D.L., Durand, R.M., Dreves, R.A., 1976. The use of a multi-attribute attitude model in a store image study. Journal of Retailing 52 (2), 23-32.

Jarratt, D., 1996. A shopper taxonomy for retail strategy development. The International Review of Retail, Distribution and Consumer Research 6 (2), $196-215$.

Jin, B., Kim, J.-O., 2003. A typology of Korean discount shoppers: shopping motives, store attributes, and outcomes. International Journal of Service Industry Management 14 (4), 396-419.

Johnson-Hillery, J., Kang, J., Tuan, W., 1997. The difference between elderly consumers' satisfaction levels and retail sales personnel's perceptions. International Journal of Retail \& Distribution Management 25 (4), 126-137.

Kang, Y.S., Ridgway, N.M., 1996. The importance of consumer market interactions as a form of social support for elderly consumers. Journal of Public Policy \& Marketing 15 (1), 108-117.

Karande, K., Ganesh, J., 2000. Who shops at factory outlets and why?: an exploratory study. Journal of Marketing Theory and Practice 8 (4), 29-42. 
Kim, Y.-K., Kang, J., Kim, M., 2005. The relationships among family and social interaction, loneliness, mall shopping motivation, and mall spending of older consumers. Psychology and Marketing 21 (12), 995-1015.

Klastorin, T., 1983. Assessing cluster analysis results. Journal of Marketing Research 20 (1), 92-98.

Kunkel, J.H., Berry, L.L., 1968. A behavioral conception of retail image. Journal of Marketing 32 (4), 21-27.

Labouvie-Vief, G., 2009. Dynamic integration theory: emotion, cognition, and equilibrium in later life. In: Bengston, V., Gans, D., Pulney, N., Silverstein, M. (Eds.), Handbook of Theories of Ageing, Second ed. Springer Publishing Co., New York, NY, pp. 277-293.

Lambert, Z.V., 1979. An investigation of older consumers' unmet needs and wants at the retail level. Journal of Retailing 55 (4), 35-57.

Leighton, C., Seaman, C., 1997. The elderly food consumer: disadvantaged? Journal of Consumer Studies and Home Economics 21 (4), 363-370.

Leventhal, R.C., 1997. Aging consumers and their effects on the marketplace. Journal of Consumer Marketing 14 (4), 276-281.

Lindquist, J.D., 1974-1975. Meaning of image. Journal of Retailing 50 (4), 29-39.

Lumpkin, J.R., 1985. Shopping orientation segmentation of the elderly consumer Journal of the Academy of Marketing Science 13 (2), 271-289.

Lumpkin, J.R., Greenberg, B.A., Goldstucker, J.C., 1985. Marketplace needs of the elderly: determinant attributes and store choice. Journal of Retailing 61 (2), 75-103.

Lysonski, S., Durvasula, S., Zotos, Y., 1996. Consumer decision-making styles: a multi-country investigation. European Journal of Marketing 30 (12), 10-21.

MacQueen, J.B., 1967. Some Methods for Classification and Analysis of Multivariate Observations, In: Le Cam, L.A., Newman, J., (Eds.), Proceedings of the 5th Berkley Symposium on Mathematical Statistics and Probability. University of California Press, Berkeley, CA, pp. 281-297.

Martineau, P., 1958. The personality of the retail store. Harvard Business Review 36 47-55.

Mason, J.B., Bearden, W.O., 1978. Profiling the shopping behavior of elderly consumers. The Gerontologist 18 (5), 454-461.

Megicks, P., Memery, J., Angell, R., 2012. Understanding local food shopping: unpacking the ethical dimension. Journal of Marketing Management 28, 264-289.

Memery, J., Megicks, P., Angell, R., Williams, J., 2012. Understanding ethical grocery shoppers. Journal of Business Research 65 (9), 1283-1289.

Meneely, L., Strugnell, C., Burns, A., 2009. Elderly consumers and their food store experiences. Journal of Retailing and Consumer Services 16 (6), 458-465.

Mitchell, V.W., Bates, L., 1998. UK consumer decision-making styles. Journal of Marketing Management 14 (1-3), 199-225.

Moschis, G.P., 1976. Shopping orientations and consumer use of information. Journal of Retailing 52, 61-70.

Moschis, G.P., 1992. Marketing to Older Consumers. Quorum Books, Westport, CT.

Myers, H., Lumbers, M., 2008. Understanding older shoppers: a phenomenological investigation. Journal of Consumer Marketing 25 (5), 294-301.

Muthen, L., Muthen, B., 2009. Mplus User's Guide, Fifth ed. Muthen \& Muthen, Los Angeles, CA.

Office of National Statistics, 2011. Older People's Day 2011(online). Office of National Statistics, London. Available from: 〈http://www.ons.gov.uk/ons/dcp 171778_235000.pdf $>$ (accessed 04.07.12).

Oxenfeldt, A.R., 1974-1975. Developing a favorable price-quality image. Journal of Retailing 50 (4), 8-15.

Peter, J.P., 1981. Construct validity: a review of psychometric basic issues and recent marketing practices. Journal of Marketing Research 18 (2), 133-145.
Pettigrew, S., Mizerski, K., Donovan, R., 2005. The three "big issues" for older supermarket shoppers. Journal of Consumer Marketing 22 (6), 306-312.

Punj, G., Stewart, D.W., 1983. Cluster analysis in marketing research: review and suggestions for application. Journal of Marketing Research 20, 134-148.

Reynolds, K.E., Beatty, S.E., 1999. A relationship customer typology. Journal of Retailing 75 (4), 509-523.

Reynolds, K.E., Ganesh, J., Lukett, M., 2002. Traditional malls vs. factory outlets: comparing shopper typologies and implications for retail strategy. Journal of Business Research 55 (9), 687-696.

Samli, A.C., Kelly, J.P., Hunt, H.K., 1998. Improving the retail performance by contrasting management- and customer-perceived store images: a diagnostic tool for corrective action. Journal of Business Research 43 (1), 27-38.

Schoefer, K., Diamantopoulos, A., 2009. A typology of consumers' emotional response styles during service recovery encounters. British Journal of Management 20 (3), 292-308.

Seidman, I., 2006. Interviewing as Qualitative Research: A Guide for Researchers in Education and the Social Sciences, Third ed. Teachers College Press, New York, NY.

Sharma, S., 1996. Applied Multivariate Techniques. John Wiley and Sons, New York,

Shim, S., Kotsiopoulos, A., 1993. A typology of apparel shopping orientation segments among female consumers. Clothing and Textiles Research Journal $12(1), 73-85$.

Sproles, E., Sproles, G., 1990. Consumer decision-making styles as a function of individual learning styles. Journal of Consumer Affairs 24 (1), 134-147.

Sprotles, G.B., Kendall, E.L., 1986. A methodology for profiling consumers' decisionmaking styles. Journal of Consumer Affairs 20 (2), 267-279.

Stone, G.P., 1954. City shoppers and urban identification: observations on the social psychology of city life. American Journal of Sociology 60 (1), 36-45.

Sudbury, L., Simcock, P., 2009. A multivariate segmentation model of senior consumers. Journal of Consumer Marketing 26 (4), 251-262.

Tauber, E.M., 1972. Why do people shop? Journal of Marketing 36 (4), 46-49.

Teller, C., Gittenberger, E., 2011. Patronage behaviour of elderly supermarket shoppers-antecedents and unobserved heterogeneity. International Review of Retail, Distribution and Consumer Research 21 (5), 483-499.

Theodoridis, P.K., Chatzipanagiotou, K.C., 2009. Store image attributes and customer satisfaction across different customer profiles within the supermarket sector in Greece. European Journal of Marketing 43 (5/6), 708-734.

Thompson, N.J., Thompson, K.E., 2009. Can marketing practice keep up with Europe's ageing population? European Journal of Marketing 43 (11/12), 1281-1288.

Ward, J.H., 1963. Hierarchical grouping to optimize an objective function. Journal of the American Statistical Association 58 (301), 236-244.

Westbrook, R.A., Black, W.C., 1985. A motivation-based shopper typology. Journal of Retailing 61 (1), 78-103.

Westbrook, R.A., Oliver, R.L., 1991. The dimensionality of consumption emotion patterns and customer satisfaction. Journal of Consumer Research 18 (1), 84-91.

Yoon, C., Laurent, G., Fung, H., Gonzalez, R., Gutchess, A., Hedden, T., LambertPandraud, R., Mather, M., Park, D., Peters, E., Skurnik, I., 2005. Cognition, persuasion and decision making in older consumers. Marketing Letters 16 (3/4), 429-441.

Yoon, C., Cole, C., Lee, M., 2009. Consumer decision making and aging: current knowledge and future directions. Journal of Consumer Psychology 19 (1), 2-16.

Zelnio, R.N., Gagnon, J.P., 1981. The construction and testing of an image questionnaire. Journal of the Academy of Marketing Science 9 (3), 288-299.

Zimmer, M.R., Golden, L.L., 1988. Impressions of retail stores: a content analysis of consumer images. Journal of Retailing 64 (3), 265-293. 